\title{
Introduction
}

"I cannot fix on the hour, or the spot, or the look, or the words, which laid the foundation. It is too long ago. I was in the middle before I knew that I had begun.” (Pride and Prejudice,359)

This quotation is from a well-known book by Jane Austen, Pride and Prejudice. It appears at the end of the book, where Elizabeth Bennet wants Mr. Darcy to describe how he fell in love with her. The sentence singled out here does not only fit into the story but it also fits in with how many readers feel after reading Pride and Prejudice. Several readers fall in love with the book and the characters, and some even feel it hard to let go of the book and the story. Why this should be is difficult to explain and it is also difficult to explain why Jane Austen's books have become so admired among women today. All we know is that her books speak to us even though they were written two hundred years ago. I think Jane Austen speaks to women in a way that perhaps men will never understand fully, and this is why this essay will focus on how women feel about this renowned story.

Pride and Prejudice may be Jane Austen's most popular work. She has described this novel as "her own darling child" in a letter to her sister Cassandra. ${ }^{1}$ Jane Austen also writes about Elizabeth Bennet, the main character of Pride and Prejudice and one of the most wellknown female characters in English literature, saying that "I must confess that I think her as delightful a creature as ever appeared in print, and how shall I be able to tolerate those who do not like her at least I do not know”. ${ }^{2}$ Elizabeth is the one character of Pride and Prejudice who has captured most of the readers' attention, not just because she is the main character, but also because of what she stands for and what she is going through in the book. Elizabeth is described as having a critical intelligence and a liveliness of mind. (Viviene Jones, 2003, xiii). She is lovely, clever, and, in a novel defined by dialogue, she converses as brilliantly as anyone. ${ }^{3}$ Jane Austen was proud of this special character.

\footnotetext{
$1 \quad$ http://www.geocities.com/Athens/8563/books/index.html, 2006-11-28, 12:11

2 Andrew H Wright: Heroines, Heroes, and Villains in Pride and Prejudice, 1.Elizabeth Bennet, in E. Rubinstein, Twentieth Century Interpretations of Pride and Prejudice (Englewood Cliffs, N.J.: Prentice-Hall, 1969) 97.

3 http://www.sparknotes.com/lit/pride/terms/charanal_1.html, 2006-11-28, 11:50
} 
Jane Austen did not write for any 'worthy' reason, she wrote because she wanted to and because she wanted to entertain people, and that is, I believe, the whole point about her books. She did not write sermons to make people live better lives, she wrote to give the readers fulfilment, happiness, and pleasure. Many books in the $18^{\text {th }}$ and the $19^{\text {th }}$ century were written for the purpose of telling people what to do and how they should live their lives. An example of that is the book entitled "Advice to Young Ladies on the Improvement of the Mind and Conduct of Life"; it was published only three years before Pride and Prejudice. ${ }^{4}$ One of the reasons for Jane Austen's enduring success, as Paul Webster points out, could be that she wrote about a world she knew and thoroughly understood. ${ }^{5}$ She only wrote of her direct experience, and because she used comic observation, to a large degree, she is more accessible than many classic writers. Despite the fact that the story was set in the early $19^{\text {th }}$ century's environment it suits today's environment well.

The aim of this essay is to get some more answers why Pride and Prejudice still affects some of its female readers and what it is in the character of Elizabeth Bennet that makes some of them want to be her. Schweickart and Flynn say that ". . . identification should be considered a significant part of the emotional appeal of any text, involving as it generally does 'experiencing the text fully, living through the events of the text as they are encountered."'6 I will focus on how women interpret this story and identify with the character of Elizabeth Bennet.

\section{Jane Austen}

Jane Austen was born on December 16, 1775 in the village of Steventon in Hampshire, England. She was the seventh of the eight children of Reverend George Austen and his wife Cassandra. ${ }^{7}$ Jane did a lot of her early writing at Steventon until she was twenty-five, when her father retired and the whole family moved with him to Bath. ${ }^{8}$ In 1805 her father died and

\footnotetext{
$4 \quad$ http://www.geocities.com/Athens/8563/books/index.html, 2006-11-28, 12:11

5 Paul Webster, publisher, Pride and Prejudice, Joe Wright, 2006, DVD bonus material

6 Patricinio P. Schweickart and Elizabeth A. Flynn, eds., Gender and Reading: Essays on Readers, Texts, and Contexts , 39, quoted in Hildebrand, The Female Reader at the Round Table: Women and Religion in Three Contemporary Arthurian Texts, doct. diss, Uppsala, 2001.

7 Rubinstein 1.

8 Vivien Jones, Introduction, 2003, Jane Austen, Pride and Prejudice, (1813; Harmondsworth: Penguin Classics, 1996) ix.
} 
the family left again for Southampton, but three years later Jane, her mother, her sister and their friend Martha Lloyd moved back to Steventon. From the year they left Steventon until they moved back Austen's writing went through a very arid period and she did not do any of her 'major' writing during that period. Steventon was the place where she would do her famous writing. The Village of Steventon also came to be the place where Jane remained until shortly before her death on July 18, 1817. She reached the age of forty-one.

Jane Austen had no formal literary training and she enjoyed no connections with the literary society of her time. ${ }^{9}$ The only school mentioned in her life is the Abbey school, which she and her sister attended. ${ }^{10}$ She liked to read a lot of literature, and her favourite authors were Ann Radcliffe, Henry Fielding, Laurence Sterne, Samuel Richardson, Fanny Burney and Maria Edgeworth. ${ }^{11}$ Her life was not a large one; she did not live a life in the public eye. She used her unofficial life to make observations of human behaviour that are as true today as they were then. ${ }^{12}$ She was an observer of the nature of man in society. ${ }^{13}$

An ordinary day in Jane Austen's' life could look like this: in the morning she would get up early and she would go and practise the piano. Then she would probably be writing after breakfast, writing secretly at her tiny little table in the dining room. To get into the room there was a door you had to pass, and it was a door that used to creak, so Austen was then able to hear if anyone came in. She did not want anyone to know that she was writing. It was not that she thought it was a disgrace to be writing. It was because she valued her privacy and did not want people to interrupt her, saying "Why don't you do this?” which would be so tedious. Even though she wrote in secrecy she has refered to her own fiction as "the little bit (two inches wide) of ivory on which I work with so fine a brush, as produces little effect after much labour.”,14

Jane Austen was certainly, like almost every girl, looking for love, but according to the norms of society she had to be in love with somebody in her own social sphere. In the late $18^{\text {th }}$ century you could not choose to marry someone just like that, if you were going to have a comfortable life and not have to worry about food, clothes, and somewhere to live. Jane Austen fell in love with a man named Tom Lefroy when she was twenty. They were both very

\footnotetext{
$9 \quad$ Rubinstein 1.

10 Jones ix.

11 http://www.bbc.co.uk/dna/h2g2/A847505, 2006-11-28, 12:00

12 Louise West, Pride and Prejudice, Joe Wright, 2006, DVD bonus material

13 http://www.123helpme.com/assets/16770.html ,2006-11-28, 11:55

14 http://geocities.com/Athens/8563/essays/essay5.html, 2006-11-28, 12:10
} 
respectable people from the same social class, but because he did not have any money, and still had his way to make in the world, his family soon put a stop to it. He was taken back to Ireland whence he came. ${ }^{15}$ When Jane was twenty-seven she accepted a proposal of marriage from Harris Bigg-Wither, but the following day she changed her mind. ${ }^{16}$ Jane Austen never married anyone and that was not because she had experienced disappointments in love, she just did not get married. Also her beloved sister Cassandra remained unmarried. Austen gave most of her life to her family and she was said to have inspired warm affection in those who knew her the best. ${ }^{17}$

To our generation Jane Austen's work is known as famous and well-written. In her time they were not only praising her work, there were also complaints about it,

...the accusation most regularly brought against her work is that its concerns are relatively trivial. From the earliest reviewers to very recent critics, one complaint - and a complaint it remains, however richly framed by words of the highest praise - is heard again and again: "What she does, she does well, perhaps better than anyone - though of course we all know that there is so much more to life and to literature than this.”18

The liberals of Jane Austen's' time considered her a “humble chronicler of her society’s customs”19 and they neglected her artistic development as well as her social criticism. Ralph Waldo Emerson said;

“I am at a loss to understand why people hold Miss Austen's novels at so high a rate, which seem to me vulgar in tone, sterile in artistic invention, imprisoned in their wretched conventions of English society, without genius, wit, or knowledge of the world. Never was life so pinched and

\footnotetext{
15 Louise West, Pride and Prejudice, Joe Wright, 2006, DVD bonus material

16 http://www.bbc.co.uk/dna/h2g2/A1171595, 2006-11-28, 11:59

17 Rubinstein 1.

18 Rubinstein 5-6.

19 Philip Goldstein, Communities of cultural value (Lanham, MD : Lexington Books, 2001) 88.
} 
narrow...all that interests in any character [is this]: has he or she the money to marry with? Suicide is more respectable. ${ }^{20}$

In 1821, when Jane Austen was still alive, Richard Whately said that "certainly no author has ever conformed more closely to real life, as well as the incidents, as in the characters and descriptions", Whately also said that "her fables appear to us to be in their own way, nearly faultless". ${ }^{21}$ Sir Walter Scott said “That young lady had a talent for describing the involvement and feelings and characters of ordinary life which is to me the most wonderful I have ever met with.” 22 Many voices were raised to praise Jane Austen and her works or to bring them down.

Unfortunately Jane Austen did not live long enough to experience the success her work achieved later and still maintain today. Only four of her novels got published while she was alive; these were Sense and Sensibility (1811), Pride and Prejudice (1813), Mansfield Park (1814) and Emma (1815). They did not give much money or much acclaim, not as much as the novels of Fanny Burney or Maria Edgeworth, her more or less forgotten contemporaries. ${ }^{23}$ Jane Austen has described her own work Pride and Prejudice as "rather too light and bright and sparkling”. ${ }^{24}$ It might have been that she did not believe in herself and her capability.

Joe Wright, the director of the latest film version of Pride and Prejudice, say's that there is no doubt that Jane Austen changed the face of the novel. He also says that her characterisation is much deeper than in earlier writing and that the psychology of the characters is something that you do not really get in literature beforehand. As readers we feel that she was honest and wrote completely from her heart. It is said that the modern novel owes more to Austen in terms of structure than for example Henry Fielding's Tom Jones or Samuel Richardsson's Clarissa. When Jane Austen was writing, the novel was in its infancy and many $18^{\text {th }}$ century novels were sprawling, often epistolary affairs, long-winded and melodramatic. $^{25}$

Jane Austen was the first English writer to confront the real challenges of the form in which she operated. The technical challenge was that of focusing on the mind of at least one

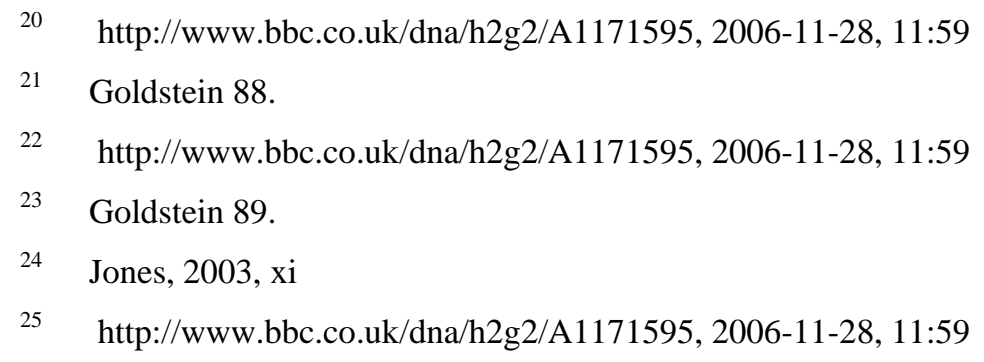


central character while at the same time allowing that character's world and its many inhabitants to impose themselves independently upon the reader's attention. In Pride and Prejudice Jane Austen chooses to focus on the consciousness of one central figure, Elizabeth Bennet, from whose point of view the narrative is for the most part experienced. ${ }^{26}$

Lady Victoria Leatham, also working with the production of the film Pride and Prejudice, points out that Austen's books allow us to see behind the scenes and see the domestic trivia,

"She really manages to put us in the actual scene of everyday life from breakfast through to tea. We can see how the families had these pointless lives, and yet there were all sorts of undercurrents going on at the same time. Their days must have been so dull and so boring, especially if a girl had a good brain. To spend your life sewing and tittle-tattle, and wandering between coffee mornings, with your mother clucking over you like an old hen". ${ }^{27}$

We do not realise how lucky we are today. An example of this from the book really points out how uneventful their lives might have been.

When tea was over...Mr. Hurst had therefore nothing to do, but to stretch himself on one of the sophas and go to sleep. Darcy took up a book; Miss Bingley did the same; and Mrs. Hurst, principally occupied in playing with her bracelets and rings, joined now and then in her brother's conversation with Miss Bennet. (P\&P, 53-54)

Pride and Prejudice is not only a romantic love story where boy meets girl, its undertones strongly satirise contemporary society: Pride and Prejudice is written as a romantic comedy whose depiction of the characters' confusions and difficulties forcefully satirises middle-class ideals of romance and marriage. Pride and Prejudice also criticizes the social life of its time.

\footnotetext{
26 Rubinstein 11.

27 Lady Victoria Leatham, Pride and Prejudice, Joe Wright, 2006, DVD bonus material
} 
It satirises the middle class vulgarity of Mrs. Bennet, the childish frivolity of Lydia and Kitty, the aristocratic snobbery and arrogance of Darcy, Miss Bingley, and Lady Catherine, and the servile pomposity of clergymen like Mr Collins, the novel also exposes the self-indulgent sarcasm, permissiveness, or dependence of middle-class gentlemen like Mr Bennet and Mr Bingley and the cynical conformity or complacent indifference of middle-class women like Jane Bennet and Charlotte Lucas. ${ }^{28}$

When we look deep into the text and analyse it, there are more things being criticized. The story develops less familiar but more subversive notions of reading and interpretation this means that the novel assumes, in other words, that serious public reading ends up boring and pretentious, while sceptical private reading can demonstrate genuine intelligence. ${ }^{29}$ Trevor Ross said that "...true pleasures of reading could only come in relation to texts of an intellectually demanding nature" ${ }^{30}$ His educators feared that novels, which could be consumed "too easily and too rapidly", had "injurious effects". In that time the Victorian liberals expected reading to improve the reader and to improve their intellect. ${ }^{31}$

\section{The life of the character Elizabeth Bennet}

Elizabeth Bennet, the daughter of Mr. and Mrs. Bennet, is the main character of Pride and Prejudice. She lives at Longbourn in Hertfordshire with her parents and four sisters, Jane, Mary, Kitty/Catherine, and Lydia. Elizabeth is a young woman of twenty who, like other girls, dreams of marriage and love.

The depiction of her is as by nature capable of much happiness and enjoyment in life, she is a woman of deep feeling and strong convictions, and she is very protective of her sisters and capable of righteous anger. "She is honest, outspoken, and uncompromising and seems very much at home with herself. Lizzy does not care what people whom she does not like think of her and readily speaks her mind.”33 An example of this is when Elizabeth talks to her

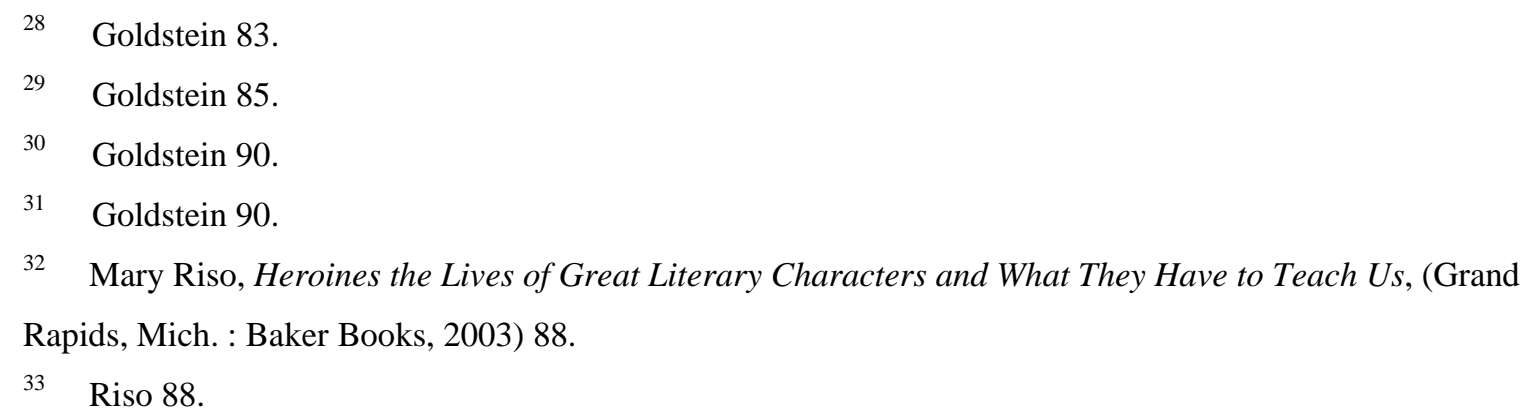


sister after finding out that the assembly containing the beloved Mr. Bingley is leaving Netherfield, which is assumed to be a trick by Bingley's sisters who do not think Jane a suitable wife for their brother.

\begin{abstract}
“There are few people whom I really love, and still fewer of whom I think well. The more I see of the world, the more I am dissatisfied with it; and every day confirms my belief of the inconsistency of all human characters, and of the little dependence that can be placed on the appearance of either merit or sense. I have met with two instances lately; one I will not mention; the other is Charlotte's marriage. It is unaccountable! In every view it is unaccountable!” (P\&P, 133)
\end{abstract}

Here she unreservedly speaks her mind to her sister as so often before. But her sister has not got the power or will to think ill of any one. They are in some aspects opposites of each other. Her elder sister Jane is the beauty while Elizabeth is described as ordinary, attractive but not beautiful.

Elizabeth is an independent woman who goes her own ways, which in her case has two distinct meanings; she is not moved by everything she hears and she decides for herself what to think and how to act; she also does a lot of walking in the surrounding landscape. She likes the freedom the out-of-doors gives, and the fresh air that makes it easier to think, she also likes to read and dance. Elizabeth has similarities with Jane Austen, who, as a young woman, enjoyed long country walks, she attended balls in many of the great houses of the neighbourhood because she took great pleasure in dancing and we also know that reading was a thing she liked to do. ${ }^{34}$ That Elizabeth likes to walk was seen as odd and different. In the beginning of the book she walks the three miles over to Netherfield to take care of her sister who has caught a cold riding horseback to the same place. And the Bingley sisters are upset about her behaviour.

"Why must she be scampering about the country, because her sister had a cold? Her hair so untidy, so blowsy!” “ To walk three miles, or four miles, or five miles, or whatever it is, above her ankles in dirt, an alone, quite alone! What could she mean by it? It seems to me to shew an abominable

\footnotetext{
34 http://www.jasa.net.au/jabiog.htm, 2006-11-28, 12:18
} 
sort of conceited independence, a most country town indifference to decorum.” (P\&P, 36)

Instead of walking she could have taken a carriage or been ridden a horse, but Elizabeth liked to walk and so she does, not to upset anyone, just because she wants to. She is different from the other women of her time but at the same time she is very much like them.

Elizabeth realises that she must take responsibility for her own education because she cannot look to either of her parents for advice, and she must ultimately depend on her own experiences, instincts, and judgements. ${ }^{35}$ This might have led to her pride, from which she unconsciously suffers. One could argue that she in some aspects was born in the wrong family, with her hopeless mother who only has marriage in mind and the lack of guidance and strength from her father. ${ }^{36}$ One should not forget that her mother, apart from talking very much and very loudly, also is obsessed with getting her daughters married, which could be seen as a considerate quality but in her case it is exaggerated. Elizabeth's behaviour as it is described in Pride and Prejudice was not very common in the $18^{\text {th }}$ century but in the story there are few objections to it: she is supported, in almost every move she makes, by her father who loves her very much.

Elizabeth and her father have a very warm and respectful relationship. She often speaks her mind to him in his library where he hides from the rest of the family. He cares more about her than his wife and he thanks God for his beautiful and intelligent daughter. An example from the book clearly shows his care for her and her life when Mr. Darcy of whom she has not spoken so well, proposes to her. She tells her father that she actually loves him now, more than ever, and regrets what she has said before.

"I know your disposition Lizzy. I know that you could be neither happy nor respectable, unless you truly esteemed your husband; unless you looked up to him as a superior. Your lively talents would place you in the greatest danger in an unequal marriage. You could scarcely escape discredit and misery. My child, let me not have the grief of seeing you unable to respect your partner in life”...”Well, my dear,” said he, when she ceased speaking,

\footnotetext{
35 http://www.123helpme.com/assets/16770.html 20061128 11:55

$36 \quad$ Riso 86-87.
} 
"I have no more to say. If this be the case, he deserves you. I could not have parted with you, my Lizzy, to any one less worthy.” (P\&P, 356)

Her father's opinions are important to her even though she usually does not let anyone affect her thoughts and emotions, but subconsciously we all know that she is being affected by whatever Mr. Darcy says. Auerbach points out the following; "the absurd authority of a Lady Catherine or a Mrs. Bennet implies that what Elizabeth chooses or what she learns does not matter because Austen shows that only the male authority of a Darcy or a Mr. Bennet can effectively legitimate a woman's claims.”37

\section{Courtship and Marriage}

As shown in Pride and Prejudice, one of the dominant features of social life in Austen's time was courtship and marriage. In the $18^{\text {th }}$ and $19^{\text {th }}$ century the subject of courtship was absolutely central in life and it remained so because it involved both with the social perpetuation of the family line through inherited property and, with that, larger interpenetration of social classes. The social scene was very busy; people would go around and stay with their relations a lot. Pride and Prejudice points that out very well through all the trips to different families and relatives. In this time you did not just stay for the weekend like we do today, usually they stayed for weeks: trying to get their children married, trying to make the most of the lives they had.

Courtship and marriage was important for a woman to make her way in life. At the end of the $18^{\text {th }}$ century, women's position in society had not progressed much since the $16^{\text {th }}$ century. Women were not allowed to vote and their purpose in life was to take care of the children and the household. The only way a woman could advance on the social ladder were to have good connections and to marry into the rich and wealthy families. Proposals was nothing thrown over you now and then so you had to find your partner or likely partner and be together with that person as much as possible.

Unlike the situation we are living in today, dating was not a simple thing. In our modern society we go around dating like we want, whenever we want. We meet our partner at a disco or a bar, some meet at work, school, or other places. Some people meet each other through friends or over the internet, some of these decide together where they are to meet, some meet at a cinema, which is rather strange because you cannot talk to each other during a movie. It

\footnotetext{
37 Goldstein 102-103.
} 
can be romantic and cosy in the dark but you do not get much information from the other one. Some people meet at a café, where it is easier to talk, and you can sit there as long as you like. To talk with another person makes it also a lot easier to get to know the person you might be in love with. In our time there are many alternatives of how to do it when it comes to dating. But the life of the $18^{\text {th }}$ century had another way of handling this subject. There were certain rules to follow when it came to courtship, which might have made it all easier compared to the ways we use today.

Let us compare briefly on how we greet each other today and then. The most common way we use today is to shake hands, if we are more friendly we kiss each others' cheeks, embrace each other and so on, there are so many ways of greeting another person which makes it more difficult to tell from situation to situation of how we are to greet a person. How many of us have not stretched out our hand to shake hands when the other person starts to embrace us. In the Austen period women simply did not shake hands with men.

Courtship, too, was different from today's dating. The most acceptable way to behave for a woman looking for a husband was to look like you did not want any husband. ${ }^{38}$ You should not make a fool of yourself or be too open with your feelings. So how they did manage to find each other then, was through their balls and their dance floors. It was on the dance floor you would find a good husband and a good wife. Men and women were able to be together without a chaperone and were able to talk to each other. You could dance with someone that you on a normal day would not approach and talk to. But if and when you went to a dance, or if there were a dance at the end of a party, your parents would probably always be present and you would have your mother and father watching every move you make. ${ }^{39}$ Behaviour was very important to show who you were. Elizabeth's mother was not the best representative of behaviour but she seems to know, anyway, how to behave when she exhorts Elizabeth in the following lines.

\footnotetext{
"Lizzy," cried her mother, "remember where you are, and do not run on in the wild manner that you are suffered to do at home.” (P\&P,42)
}

Mrs. Bennet is known to speak much and loudly and so does Elizabeth too, not loudly but she speaks her mind. Mrs. Bennet is afraid Elizabeth will make a fool of herself, and what is

\footnotetext{
38 Louise West, Pride and Prejudice, Joe Wright, 2006, DVD bonus material

39 Louise West, Pride and Prejudice, Joe Wright, 2006, DVD bonus material
} 
funny about that is that she admonishes Elizabeth when she should take a look at herself and her own behaviour instead.

Elizabeth has no problems when it comes to the social matter of conversations, but general knowledge confirms that it is difficult to talk to someone who you are in love with. In the time of Jane Austen you were not allowed to talk to someone of the other sex alone, except for when dancing. It was difficult, then, if you could not come up with a subject to discuss. In the following quotation Elizabeth is looking for information from Mr. Darcy and she is very upset with him when he does not give her the answers she wants.

"It is your turn to say something now, Mr. Darcy.-I talked about the dance, and you ought to make some kind of remark on the size of the room, or the number of couples.”(P\&P, 90)

She is pushing him to speak. If you could not come up with a subject to talk about, you could always talk about the dance, one could compare it with our way of talking about the weather when we run out of interesting topics. During a dance was the only time the couples were alone, so to be able to use those dances in that way was a great way of forming creating contact between the lovers. Dancing with somebody was the only way allowed to have physical contact with another man or woman outside of marriage. ${ }^{40}$ That also made the whole thing very exciting. There were of course many more rules to follow which will not be mentioned in this essay.

Courtship often led to marriage, and marriage was then, unlike today, of primary importance to the whole family. When it comes to marriage we are free to marry who we like, in today's Western society that is. Today you are also assumed to marry for love. In the society of Austen's period you were not that free, as mentioned above, to choose whom you wanted to marry. In some cases your parents already had chosen from your birth whom you were to marry. This is a little bit like parts of the Eastern society of today, where in some cases your parents chose your partner. It was also important that you married well so that you could help support you family. Especially the oldest girl in a family was under pressure to find a rich man and marry. In Pride and Prejudice this takes another turn when Lydia puts her sisters into danger of not getting married when she runs off with Mr. Wickham. Living with a

40 Joe Wright, Pride and Prejudice, 2006, Universal, DVD, bonus material 
man before marriage in that period would ruin not only Lydia's reputation but also her sisters' and perhaps destroy their prospects of marrying into a respectable family. Of course every girl wanted to marry into riches and into respectable families. But in Lydia’s case she just wanted to get married before her sisters, even though that was not the intention of Mr. Wickham running off with her. Lydia really enjoys getting married before her sisters and seems not to notice that her husband finds no interest in her.

\begin{abstract}
“Ah! Jane, I take your place now, and you must go lower, because I am a married woman.” She longed to see Mrs. Phillips, the Lucasses, and all their other neighbours, and to hear herself called “Mrs. Wickham”, by each of them; and in mean time, she went after dinner to shew her ring and boast of being married, to Mrs. Hill and the two housemaids....”I am sure my sisters must all envy me. I only hope they may have half my good luck”. (P\&P, 300)
\end{abstract}

Lydia is a very frolicsome and silly girl not older than sixteen and all she cares about is love from a handsome man. It is well described in the quotation above that she is not very mature.

Today we connect marriage mostly with love and not convenience but in Austen's time it was different. Marriage was and still is something that almost every girl dreams of. Who is going to be their prince and what will the actual wedding be like? As one can see in Pride and Prejudice, girls' heads were filled with marriage and dresses and balls. They wanted to be secure, they wanted to have a good time, and they wanted to find a likeable person to be with, which was not always possible in that day and time. People sometimes married for convenience. $^{41}$

The novel makes clear, in the figure of Charlotte Lucas, that to give oneself to a man without desire, to accede to a polite form of prostitution, is to sacrifice what is most valuable in the self, and in the figure of Mr. Bennet, that to submit to lust, or even a giddy impulse (why else would Mr. Bennet have selected the bride he did?) is to forego the possibility of rational happiness. $^{42}$

\footnotetext{
41 Joe Wright, Pride and Prejudice, 2006, Universal, DVD, bonus material

42 Rubinstein 7.
} 
It is a very good point and it is also very easy to trace in this story. Jane Austen was well aware of the subject - marrying for convenience - when she included the part where Charlotte Lucas marries Mr. Collins. And at the same time she satirizes people who marry out of attraction. The following text in her Pride and Prejudice is to me both comic and tragic.

Her father captivated by youth and beauty, and that appearance of good humour, which youth and beauty generally give, had married a woman whose weak understanding and illiberal mind, had very early in their marriage put an end to all real affection for her. Respect, esteem, and confidence, had vanished for ever; and all his views of domestic happiness were overthrown. But Mr. Bennet was not of a disposition to seek comfort for the disappointment which his own prudence had brought on, in any of those pleasures which too often console the unfortunate for their folly or their vice... To his wife he was very little otherwise indebted, than as her ignorance and folly had contributed to his amusement. This is not the sort of happiness which a man would in general wish to owe to his wife... (P\&P, 229)

As mentioned above you sometimes married for convenience, so it was not recommended to refuse a proposal as Elizabeth actually does twice in the story. Marriage proposals might just come once in a lifetime. But Elizabeth is a strong minded woman and certainly knows that she can neither love nor respect Mr. Collins, who proposes to her in a laughable way;

"Believe me, my dear Miss Elizabeth, that your modesty, so far from doing any disservice, rather adds to your other perfections. You would have been less amiable in my eyes had there not been this little unwillingness; but allow me to assure you that I have your respected mother's permission for this address. You can hardly doubt the purport of my discourse, however your natural delicacy may lead you to dissemble; my attentions have been too marked to be mistaken. Almost as soon as I entered the house I singled you out as the companion of my future life. But before I am run away with by my feelings on this subject, perhaps it will be advisable for me to state my reasons for marrying...” (P\&P, 103) 
After this Mr. Collins continues to talk about how Lady Catherine has suggested a marriage for him. Elizabeth explains to him that she cannot agree to this proposal and Mr. Collins begins to tell Elizabeth that she might never get married if she does not accept this proposal. This has no impact on Elizabeth who continues her life as usual. Then Mr. Darcy proposes to her but Elizabeth can not accept this proposal made by Mr. Darcy, which actually starts out very well,

"In vain have I struggled. It will not do. My feelings will not be repressed. You must allow me to tell you how ardently I admire and love you.” (P\&P, 185)

But Mr. Darcy continues in a very annoying fashion. He is criticising her family and their behaviour while proposing to her and I believe we all would have said no to such a proposal.

Pride and Prejudice presents different kinds of marriage. We know that Elizabeth refuses two proposals. Elizabeth does not believe in marrying for convenience and that is why she so arrogantly refuses Mr. Collins proposal. Instead Elizabeth’s best friend Charlotte Lucas accepts a proposal from Mr. Collins. The marriage is based on economics rather than on love. This was, as mentioned before, common during Jane Austen's time; women married for convenience to save themselves from spinsterhood or to gain financial security. Another kind of marriage is the hasty marriage between Mr. Wickham and Elizabeth’s sister Lydia. It was seen as a bad marriage and Austen shows here that these marriages, acting on impulse, based on superficial qualities, quickly cool and lead to unhappiness. A happy and strong marriage takes time to build and must be based on mutual feeling, understanding, and respect. It is clearly shown in the relationship between Elizabeth and Mr. Darcy. This couple takes their time and they allow themselves to get to know each other before an engagement. We know that their road to an engagement is long and filled with meetings and quarrels before they decide for love and marriage.

\section{Pride and Prejudice today}

When searching the Internet for information about Jane Austen, and Pride and Prejudice, many sites will be found, but what is most surprising are all the webpages about Elizabeth Bennet that also are to be found. Fan listing pages are very common today. You make these pages about your favourite actor or actress and so on, but pages dedicated to a character of a 
story are not that common. In Elizabeth Bennet's case, there are several pages dedicated to her; even at the famous Wikipedia page, the free encyclopaedia, there is a whole chapter simply about Elizabeth. This page relates, among other things, which actresses have portrayed Elizabeth. ${ }^{43}$ Other pages that are devoted to the character are very well made, you can find all the different dresses that Elizabeth wore in the miniseries from 1995 made by BBC. ${ }^{44}$ You can download several pictures of Elizabeth but I would say that they are pictures of the actresses playing Elizabeth. There are even 'icons' to download so that you can use them on your own webpage. The icons are pictures of Elizabeth with small notes on saying things like "I'll just smile” or "lovely”, commenting on the way she looks in the picture. On one of these webpages, there is a competition where the challengers are given themes and are then to create pictures from the movie with the theme. These challenges are made repeatedly on this page and you can look at the winning picture of the various themes. ${ }^{45}$ Pride and Prejudice quizzes can also be found, they tell you if you are a real Pride and Prejudice expert, which one of the characters you would be, and which of the male characters would suit you the best. ${ }^{46}$ On another page there are something called codes, which are also small pictures of Elizabeth with just her name on them in different types of writing, and the webmaster asks the members to upload more of those codes. ${ }^{47}$ On most of the pages you can read the story, too, and make comments on almost everything concerning Pride and Prejudice. There are also quotations of Elizabeth, to read if you do not want to read the whole book. There is so much to be found on the Internet when it comes to Elizabeth Bennet. A search on her name at a community page, containing online diaries, gave three hundred and eighty two matches: all of them webpages with "Lizzy stuff”. For just a character in a very well written book from the early $19^{\text {th }}$ century, she is very popular.

\section{Identifying with Elizabeth today}

Elizabeth's life is not as predictable and dreamlike as the life of other characters in some of the $18^{\text {th }}$ and $19^{\text {th }}$ century fiction. Her life is not a rosegarden, she has been through both luck and misfortunes, but in the end she gets married to the prince and receives the castle. Her life

\footnotetext{
43 http://en.wikipedia.org/wiki/Elizabeth_Bennet 2006-11-15, 15.15

44 http://www.austen.com/costumes/ 2006-11-15, 15.00

45 http://community.livejournal.com/austen_stills, 2006-11-15, 15.30

46 http://www.strangegirl.org/austenquiz/ 2006-11-28, 11:55

47 http://www.mourning-love.net/elizabeth/ 2006-11-15, 15.10
} 
looks a lot more like our lives today: a constant search for love and respect, except that she has no career or work taking up her time. Her days are filled with what she wants to do or what she has to do about the household. Elizabeth is a free woman in our eyes; she speaks her thoughts and her mind, which might be equal to our time's expression of girl power ${ }^{48}$. She refuses two proposals, as have been mentioned before, but she also accepts the third and last one from Mr. Darcy. That she actually gets the wealthy man in the end, as in every fairy tale, is something people still dream of.

Elizabeth has the things we long for. She has a family that she loves and a home. In today's society these things, mentioned above, can be very fairy-like for some people, it is not to be taken for granted to have a home and certainly not to have a family who loves you. Too many families today are parted or split up because of small trivial things or by larger conflicts that never get solved and remain unresolved because they never reach the surface. Parents divorce, wars in different parts of our world separate families daily, and money is another factor which often leads to conflicts, which often leads to separation. In our society today we choose to spend our time mostly hunting money because some of us still believe that happiness only can come out of a large amount of money. We spend our time working, doing our duties, and less with our families and friends, the people whom we love. This as well might lead to separations inside families. Words can be heard from disappointed children; 'I do not know my father because he always works but my mother I love, her I see everyday'. Everything is connected, we need money to keep a home and bring food on the table, to earn money most of us have to work. More work brings more money but it takes our time instead, we get less time with our nearest and dearest which makes us unhappy and we seek happiness in material things instead, like a book that could be Jane Austen's Pride and Prejudice. We escape into a fantasy world where it is comfortable to be, and that is why I think Elizabeth becomes our heroine. She is living her life in a way we would like to live our lives, free and loving. She thinks like we do or might do in the same situation. The following quotation from the book seems like a very normal way to reason.

“A man who has once been refused! How could I ever be foolish enough to expect a renewal of his love? Is there one among the sex, who would not

\footnotetext{
$48 \quad$ “A self-reliant attitude among girls and young women manifested in ambition, assertiveness and individualism.” Oxford English Dictionary, 2001
} 
protest against such a weakness as a second proposal to the same woman?

There is no indignity so abhorrent to their feelings!”(P\&P, 322)

Elizabeth is here reflecting over her situation and her relation to Mr. Darcy. With these words Elizabeth could be a woman of today, if we just give her the time and let her live through us.

As said before some of us want to be like Elizabeth, independent, speak our minds openly, and walk our own ways without being afraid of what others might say. Human beings want to be free and also free from the things that bind them in their everyday life, things like school, work, and duties at home. Society forms us no matter what we say and think about it. We are moved by things that happen in the world and we do get affected by what the neighbours tell us or what we hear about on TV. In Austen's time people were affected by what they read and we still get affected, as we can see, by reading her Pride and Prejudice. It still has its influence on us today, two hundred years after it was written.

This story, two hundred years old, still affects some people so much that they come to feel like they own Elizabeth - or some other character in the book - and believe they have a right to decide over the character. When a play is to be performed, some people have to know who is going to play what character. And when they find out they might argue that some actor or actress is absolutely wrong for that role and he or she cannot do justice to that character. This happened when the latest film version was to be recorded. The actors and actresses got questions from their friends and surroundings, "Which actor was going to play that character?" and "How could they chose that actor to that role, that is totally wrong", and so on. ${ }^{49}$

Looking at Elizabeth, then, she becomes alive through reading, through the text. The reader becomes Elizabeth by connecting herself to the character, feeling what Elizabeth feels and taking her side. The character of Elizabeth Bennet could be in any story today where women are supposed to stand up for themselves and take an equal part in society. She is out of her time and could be a woman of today, with her manners and ways of looking at life, and yet she lives in her time the time of the $19^{\text {th }}$ century, the Napoleonic era. She is a heroine and that could be one of the reasons why people love her as much as they do.

Elizabeth Bennet "seems to connect most directly with the active, visible, independent identity of modern femininity". 50 Jones also says that "The qualities which distinguished

\footnotetext{
49 Tom Hollander, Pride and Prejudice, Joe Wright, 2006, DVD bonus material

50 Jones xiii.
} 
Elizabeth from the 'common heroines' familiar to contemporary audiences continue to endear her to modern readers. Elizabeth embodies a different kind of femininity from the stereotypical one that is passive, vulnerable and a child-like romantic heroine”. She is the woman some of us want to be. She does not save lives or conquer beasts but her manners are heroic in the way they are described in Pride and Prejudice. We need female heroes that are much like ourselves so that we can relate to them. It is difficult to tell why Elizabeth Bennet is a heroine for many women today but I think it has to do with her qualities, as Viviene Jones points out, "Maybe it is her liveliness and 'active sensibility' that secures our sympathy evens more." J1 Jones also says that; "Elizabeth’s sense and conduct are of superior order to those of the common heroines of novels." 52 In each of Jane Austen's six novels she provides her heroine with a good marriage, but that of Elizabeth Bennet in Pride and Prejudice is the most dazzling of all. Pride and Prejudice is the one love story which most comfortably fits the patterns of popular romantic fiction, according to Viviene Jones. ${ }^{53}$

Romance makes connections across history: it helps us identify and understand the continuities-and the differences-between the novel's significance at the same time it was written and published and the appeal it still has for modern readers. ${ }^{54}$

However, Elizabeth is also an ordinary girl who makes mistakes, mistakes that people do today too, like judging too quickly. "Pride and prejudice are faults; but they are also the necessary defects of desirable merits: self-respect and intelligence."55 She admits to herself that she regrets her refusal of the proposal from Mr. Darcy, but in the same breath she does not feel remorse at all.

“And of this place,” thought she, "I might have been mistress! With these rooms I might now have been familiarly acquainted! Instead of viewing them as a stranger, I might have rejoiced in them as my own, and welcomed

\footnotetext{
$51 \quad$ Jones xxiv.

52 Jones xii.

$53 \quad$ Jones xi.

54 Jones xii.

55 Wright, Heroines, 97.
} 
to them as visitors my uncle and aunt.-But no,”-recollecting herself,-“that could never be: my uncle and aunt would have been lost to me: I should not have been allowed to invite them.” This was a lucky recollection-it saved her from something like regret. (P\&P, 236)

That mistake could have given her access to Pemberley and all the riches, but she acts just like I think anyone would have done. Of course we want riches and if we are close to get it but fail we will regret it. Her acting and thinking is so natural that we take her for a real person.

In Pride and Prejudice Elizabeth is prejudiced against Mr. Darcy who first attracted her and she, naturally, takes an interest in another man who seems nicer and certainly has the 'looks'. She falls for a man in uniform, a soldier, and who has not fallen for a soldier who looks handsome? Just look at the way Mr. Wickham is described in the book.

His appearance was greatly in his favour; he had all the best party of beauty, a fine countenance, a good figure, and very pleasing address. The introduction was followed up on his side by a happy readiness of conversation-a readiness at the same time perfectly correct and unassuming. (P\&P,71)

The officers of the-shire were in general a very creditable, gentlemanlike set, and the best of them were of the present party; but Mr. Wickham was far beyond them all in person, countenance, air, and walk, as they were superior to the broad-faced stuffy Uncle Philips, breathing port wine, who followed them into the room. (P\&P, 75)

In these two quotations Mr. Wickham is described as the best looking man of his time, today we look at other things but the feelings are the same. Men or women in suits or uniforms have always attracted the opposite sex. Maybe men in uniforms attract women more than the other way around. What it is that makes people more attractive when they are dressed as soldiers, police officers or fire fighters is difficult to tell by just looking at what they are wearing. I do not think it is the colours of their clothes or how they are designed or how they actually fit the person wearing them that matters. I believe it is what their uniforms stand for, they stand for the things that we search for: security and protection, for some people they might stand for 
danger, and in some cases they might stand for wild things. What the uniforms symbolize is what we want or would like to have in our partner. Looking at it from that point of view it is not so extraordinary to be attracted by a soldier or someone else in a uniform. Elizabeth and her sisters are attracted by these sorts of men. Women through all time have been attracted to these men.

Then one could argue that Mr. Darcy, who is not a soldier, is still very attractive. His way of behaving and having a very gentlemanlike nature are also very attractive. We do not know much about the way he looks like but he attracts us through his way of being. He is well articulated in speech, he is wealthy, and he is a very sophisticated man. Mr. Darcy is a calm man and he thinks before he speaks, this to me brings associations with security. He has what Elizabeth wants and what some of the women of today still search for in a man. These things are in his favour and they make us like him even though he proposes to Elizabeth in a very impolite way the first time. Mr. Darcy is the romantic gentleman some women want and Elizabeth is the woman who dares to put herself up against patriarchal society, the woman some want to be, they are our heroes in the daily life.

\section{Conclusion}

My thoughts after reading and analysing this book is that Pride and Prejudice is written so well and that it is written in a way that still catches our attention. The people Jane Austen was writing about were real people, and they were put in real situations that we can identify easily with today. She deals with very simple "boy-meets-girl" set-ups, despite the entire social decor around it; the stories are universal and speak very much to us down the generations. The narrative method that Jane Austen herself arrived at in the final version of Pride and Prejudice will probably seem so familiar and so natural to the modern reader that they may need to be reminded that it was, if not invented, at least perfected by her, before being absorbed into the mainstream of English fiction. It gives the reader a sense of involvement and makes it uncomplicated for the reader to become the character while reading. Further more, "it puts the reader in a moral position at once committed and disengaged with respect to the difficulties and weaknesses of the heroine-bound to Elizabeth in her confusions and errors, yet amused and fascinated by the stubborn fidelity to her own original opinions which so complicates her struggles." 56

$56 \quad$ Rubinstein 12. 
None of Austen's novels are so immediately and directly accessible as Pride and Prejudice, oddly enough it may be these qualities that the modern reader particularly admirers and what kept it from pleasing some of the readers of its own century. P. Goldstein argues that what definitely affects us while reading Pride and Prejudice is that it is simple and realistic and we value it for its good plot, effective irony, not for its moral truth, liberal values, realistic depiction's, feminist beliefs or social criticism. ${ }^{57}$ I think that we as readers interpret what we want to read and ignore political values if we are not interested in them. We read what we want to read, no matter what the book is criticising or not criticising and if there is any irony or none.

Pride and Prejudice is relevant to society today. The reason for this is many of the themes are still being debated today, for instance feminism. The book reaches out to us two hundred years later with its characters and their lives, and this makes Pride and Prejudice special. If it did not get the attention it was worthy of when it was written, it certainly has got that now and will be given many more years, I think. Pride and Prejudice is important in today's society; we need these kinds of stories where we can easily identify with a character. Jane Austen certainly knew what she wanted and wrote about it. That this book speaks to women in a way that men will perhaps never understand fully is wonderful in the sense of the enjoyment it gives to its readers. Women get their own fantasy place to creep into, where men cannot be in the way, the women can escape the stressful world their living in. People need to escape real life a little bit now and then, and run away in to the world where they want to be: a world that is not uncomplicated but less demanding. A world with pride and prejudice; but also a world with love, beauty, family, balls, and warm affection, things which we sometimes find it hard to find in our own world. Everything we want in our lives is to be found if we know where to look, sometimes all we need is to open up a book, and fly away. "You yearn for beauty and goodness, love and mercy-rare qualities in today's world. Still, they can be found if you know where to look." 58

\footnotetext{
57 Goldstein 96.

${ }^{58}$ Riso, cover.
} 


\section{Bibliography}

Austen, Jane. Pride and Prejudice. 1813; Harmondsworth: Penguin Classics, 1996.

Goldstein, Philip. Communities of cultural value. Lanham, MD : Lexington Books, 2001.

Jones, Vivien. “Introduction.” 2003. In Austen, Jane. Pride and Prejudice.

Riso, Mary. Heroines: the Lives of Great Literary Characters and What They Have to Teach Us. Grand Rapids, Mich. : Baker Books, 2003.

Rubinstein, E. Twentieth Century Interpretations of Pride and Prejudice. Englewood Cliffs, N.J.: Prentice-Hall, 1969.

Schweickart Patricinio P. and Elizabeth A. Flynn, eds., Gender and Reading: Essays on Readers, Texts, and Contexts . Quoted in Hildebrand, The Female Reader at the Round Table: Women and Religion in Three Contemporary Arthurian Texts. Doct. diss, Uppsala, 2001.

Wright, Andrew H. "Heroines, Heroes, and Villains in Pride and Prejudice, 1.Elizabeth Bennet,” in E. Rubinstein. Twentieth Century Interpretations of Pride and Prejudice. Englewood Cliffs, N.J.: Prentice-Hall, 1969.

Joe Wright, Pride and Prejudice, 2006, Universal, DVD, bonus material

\section{Internet resources}

http://community.livejournal.com/austen_stills, 2006-11-15, 15.30

http://en.wikipedia.org/wiki/Elizabeth_Bennet 2006-11-15, 15.15

http://geocities.com/Athens/8563/essays/essay5.html, 2006-11-28, 12:10

http://www.austen.com/costumes/ 2006-11-15, 15.00

http:/www.bbc.co.uk/dna/h2g2/A1171595, 2006-11-28, 11:59 
http://www.bbc.co.uk/dna/h2g2/A847505, 2006-11-28, 12:00

http://www.geocities.com/Athens/8563/books/index.html, 2006-11-28, 12:11

http://www.jasa.net.au/jabiog.htm, 2006-11-28, 12:18

http://www.mourning-love.net/elizabeth/ 2006-11-15, 15.10

http://www.sparknotes.com/lit/pride/terms/charanal_1.html, 2006-11-28, 11:50

http://www.strangegirl.org/austenquiz/ 2006-11-28, 11:55

http://www.123helpme.com/assets/16770.html 20061128 11:55 